\title{
Metachronous colorectal cancer risk for mismatch repair gene mutation carriers - the advantage of more extensive surgery
}

\author{
Susan Parry ${ }^{1,2^{*}+}$, Aung K Win ${ }^{3 \dagger}$, Finlay A Macrae ${ }^{4}$, Bryan Parry ${ }^{5}$, Lyle C Gurrin ${ }^{3}$, Noralane M Lindor ${ }^{6}$, \\ Steven Gallinger ${ }^{7}$, John L Hopper ${ }^{3}$, Mark A Jenkins ${ }^{3}$ \\ From 14th Annual Meeting of the Collaborative Group of the Americas on Inherited Colorectal Cancer \\ Dallas, TX, USA. 12-13 October 2010
}

\section{Background}

Appropriate surgical management of colorectal cancers (CRC) in Lynch Syndrome patients, i.e. carriers of germline mutation in a mismatch repair (MMR) gene, is controversial. The decision to remove more or less of the colon requires the consideration of relatively high risk of metachronous CRC with the functional consequence of more extensive surgery. Our aim was to estimate and compare the risks of metachronous CRC for MMR gene mutation carriers following segmental versus extensive removal of colon for their first colon cancer.

\section{Materials and methods}

Risk of metachronous CRC was estimated for 382 carriers of MMR gene (172 MLH1, 167 MSH2, 23 MSH6 and 20 PMS2) mutations from the Colon Cancer Family Registry, who had colorectal surgery for their first colon cancer. Age-dependent cumulative risks were calculated using Kaplan-Meier method. Multivariate Cox proportional hazards regression was used to estimate the association between the length of bowel removed and metachronous CRC risk.

\section{Results}

Of 50 individuals who had extensive (subtotal or total) colectomy for first colon cancer, none were diagnosed with metachronous CRC over 414 person-years (incidence rate, $95 \%$ confidence interval, CI $0-7.2$ per 1000 person-years). Of 332 individuals who had segmental

\footnotetext{
* Correspondence: SParry@adhb.govt.nz

† Contributed equally

${ }^{1}$ New Zealand Familial Gl Cancer Registry, Genetic Services, Auckland City Hospital, New Zealand

Full list of author information is available at the end of the article
}

colorectal resection for first colon cancer, there were 79 (24\%) diagnoses of metachronous CRC over 3,131 person-years (incidence rate 25.2 per 1000 person-years; 95\%CI 20.2-31.5 per 1000 person-years). This incidence rate was statistically different from that for individuals who had extensive surgery $(P<0.001)$. Cumulative risk of metachronous CRC was $20 \%(95 \%$ CI $15-26 \%)$ at 10 years, $44 \%(95 \%$ CI $35-55 \%)$ at 20 years and $66 \%(95 \%$ CI $52-78 \%)$ at 30 years after segmental colectomy for a first colon cancer. Risk of metachronous CRC reduced by $24 \%$ (95\%CI 4-40\%; P 0.02) for every $10 \mathrm{~cm}$ of bowel removed. There was no difference in the frequency of colonoscopy after surgery for first colon cancer between extensive and segmental resection (one colonoscopy per 16 (95\%CI 13-20) months after extensive resection compared to one colonoscopy per 20 (95\%CI 18-21) months after segmental resection; $P$ 0.2).

\section{Conclusions}

Lynch Syndrome patients with colon cancer who have had a segmental colorectal resection have a high cumulative risk for a metachronous CRC. Patients with more extensive resection of the first colon cancer had a lower risk of metachronous CRC compared to less extensive surgery. These findings will better inform decision making about the extent of primary surgical resection.

\section{Acknowledgements \\ This abstract is presented for the Colon Cancer Family Registry and supported by the National Cancer Institute, National Institutes of Health under Request for Application \#CA-95-011.

\footnotetext{
Author details

${ }^{1}$ New Zealand Familial Gl Cancer Registry, Genetic Services, Auckland City Hospital, New Zealand. ${ }^{2}$ Department of Gastroenterology, Middlemore
} 
Hospital, Auckland, New Zealand. ${ }^{3}$ Centre for Molecular, Environmental, Genetic and Analytic Epidemiology, The University of Melbourne, Parkville, Victoria, Australia. ${ }^{4}$ Colorectal Medicine and Genetics, Royal Melbourne Hospital, Parkville, Victoria, Australia. ${ }^{5}$ Colorectal Surgical Unit, Auckland City Hospital, New Zealand. ${ }^{6}$ Department of Medical Genetics, Mayo Clinic, Rochester, Minnesota, USA. ${ }^{7}$ Mount Sinai Hospital, University of Toronto, Toronto, Ontario, Canada.

Published: 10 March 2011

doi:10.1186/1897-4287-9-S1-01

Cite this article as: Parry et al: Metachronous colorectal cancer risk for mismatch repair gene mutation carriers - the advantage of more extensive surgery. Hereditary Cancer in Clinical Practice 2011 9(Suppl 1):01.

Submit your next manuscript to BioMed Central and take full advantage of:

- Convenient online submission

- Thorough peer review

- No space constraints or color figure charges

- Immediate publication on acceptance

- Inclusion in PubMed, CAS, Scopus and Google Scholar

- Research which is freely available for redistribution

Submit your manuscript at www.biomedcentral.com/submit 